\title{
Opettajan ammattietiikka
}

\author{
Kirsi Tirri (1999) Opet- \\ tajan ammattietiikka. \\ WSOY
}

\section{Miten menetellä}

moraalisessa ongelmatilanteessa? Naapuriasi pahoinpidellään, lapsesi ystävää kiusataan koulussa, ventovieraat tappelevat kadulla? Tai kollegasi työmoraalissa on huomautettavaa, lapsesi jättää kotitehtävänsä tekemättä, työpaikallasi esiintyy sukupuolista syrjintää?

\section{Katsotaan kirjasta.}

Kirsi Tirrin kirjalla on lupaava nimi ja edellä esiintyvät teemat ovat ainakin esillä kirjassa. Antaako kirja lukijalleen aineksia ongelmien ratkaisuun?

\section{Tirri on jakanut kirjansa} kolmeen osaan: ensimmäisessä hän käsittelee opettajan ammattietiikan teoreettisia perusteita, toisessa käytännön haasteita ja kolmannessa osassa koulun eettisten ongelmien kohtaamista. Jaottelu on selkeä, mutta teoreettisesti kovin konservatiivinen ja pedagogisesti traditionaalinen. Aivan hyvin järjestyksen olisi voinut kääntää toisinpäin: lähtökohtana olisi ollut konteksti ja ongelmat sekä niiden ratkaisuvaihtoehdot, siitä olisi edetty niiden asettamiin ehtoihin opettajan ammatille ja lopulta viimeiseksi pohdittu teoreettisia vaihtoehtoja. Toki kirjaa voi lukea hyppien ja edestakaisin selaten, mutta perinteinen lukutapa kuitenkin on varmaan yleisin tapa, alusta loppuun jonkinlaista juonta etsien.

\section{Tirrin kirja on syntynyt Suomen Akatemian rahoitta- \\ nelle oikean ratkaisun.} man tutkimusprojektin "Koulun moraalidilemmat ja niiden ratkaisustrategiat" innoittamana. Tutkimuksessa kerättiin laajahko empiirinen aines yläasteen oppilailta ja opettajilta Vantaalta ja Oulusta. Tirrin "opettaja" opettaa lapsia, suuri osa opettajista jää tarkastelun ulkopuolelle, sillä suuri osa opettajista opettaa nuoria ja aikuisia. Miten heidän etiikkansa ja moraalinen toimintansa eroaa lasten opettajista? Tämä ei tule Tirrin pohdinnan kohteeksi, vaikka se olisi kiinnostavaa siitäkin syystä, että moraalisen kasvun kannalta on tärkeää, että opettaja toimii oikealla tavalla ottaen huomioon oppijoiden iän ja kehitysasteen.

\section{Tirrin kirjan teoreettisessa} osassa on kolme kiinnostavaa ja hyödyllistä eettisen tutkimuksen apuna käytettyä luokitusta. Niistä ensimmäisen, Dreyfusin (Dreyfus \& Dreyfus 1990) esittämän, mukaan eettinen asiantuntijuus kehittyy samalla tavalla kuin muukin asiantuntijuus. Aluksi ollaan noviiseja, sitten edistyneitä aloittelijoita, harjaantuneita opettajia, kokeneita opettajia ja lopuksi asiantuntijoita. Siinä missä aloittelija nojautuu ja joutuu nojautumaan tiukkoihin ennalta asetettuihin sääntöihin ja kokee epävarmuutta uusien tilanteiden edessä, asiantuntija ei sovella periaatteita tai ohjesääntöjä, vaan kuuntelee ja kerää lisätietoja tilanteesta, kunnes hänen intuitionsa kertoo hä-

\section{Toisessa Deutschin}

esittämässä teorian sovelluksessa Tirri pohtii opettajan asemaa oikeudenmukaisuuden jakajana. Yhtäläisyysperiaatteen mukaan opettajan tulisi jakaa tukeaan oppilaille tasapuolisesti, verrannollisuusperiaatteen mukaan taas ansioidensa mukaan. Tarpeiden mukaisessa jaossa taas opettajan tulisi antaa enemmän tukea sitä enemmän tarvitsevalle. Nämä eri periaatteet liittyvät erilaisiin eettisiin teorioihin. Yhtäläisyysperiaate Immanuel Kantin velvollisuusetiikkaan, verannollisuusperiaate utilitarismiin ja tarpeiden mukainen jakaminen taas Tirrin sitoumukselliseksi etiikaksi kutsumaansa näkemykseen. Käytännön opetustyössä eri opettajat menettelevät varmaankin eri tavoin, mutta myös samat opettajat eri tilanteissa noudattavat eri periaatteita.

\section{Kolmannessa teoreet-}

tisessa sovelluksessa lähtökohtana on Oserin kehittämä (Oser 1991) malli opettajan ammattietiikan tutkimiseen. Välttelyorientaatiossa opettaja yrittää ratkaista eettisen ongelman kohtaamatta sitä. Delegaatio-orientaatiossa opettaja hyväksyy ajatuksen, että ongelma koskettaa häntäkin, mutta hän pyrkii delegoimaan ratkaisun jollekulle toiselle (koulupsykologille, rehtorille jne.). Yksipuolisessa päätöksenteossa opettaja ottaa vastuun ongelmasta ja pyrkii ratkaisemaan sen yksin autoritaa- 
risesti. Osittaisessa diskurssissa opettaja kuulee oppijoiden ja muiden osapuolien kantoja, mutta säilyttää päätöksenteon ja vastuun itsellään. Täydellisessä diskurssissa opettaja jakaa vastuun oikeudenmukaisuuden, huolenpidon ja totuudellisuuden noudattamisesta oppijoiden kanssa ja pitää kiinni tästä periaatteesta myös kriittisissä ja aggressiivisissa tilanteissa.

\section{Empiirisessä osassa}

esitellään opettajien ja koululaisten vastauksia eettisiä ongelmia koskeviin kysymyksiin. Koulun moraalidilemmat Tirri luokittelee aineiston perusteella neljään luokkaan:

1 Opettajan toimintatapoihin liittyvät ongelmat

2 Oppilaiden työmoraali 3 Vähemmistöjen oikeudet 4 Koulun yhteiset säännöt

\section{Kiinnostavaa ja samalla} huolestuttavaa on, että moraalidilemmojen luettelosta puuttuu kokonaan opetuksen sisältöön liittyvät kysymykset. Tirri ei myöskään omassa tekstissään käsittele opetuksen sisältöön liittyviä asioita. Ilmeisesti sekä opettajat että oppilaat mieltävät opetuksen sisällön annettuna. Eettisessä mielessä Tirri ja useimmat opettajat ja oppilaat siis noudattavat välttelyorientaatiota: opetuksen sisällöstä ei kanneta vastuuta, vaan se siirretään opetusviranomaisten ja koululaitoksen vastuulle. Ongelmana nähdään vain se, opettaako opettaja siten, kuin opetussuunnitelmassa edellytetään. Itse opetussuunnitelmaa ei aseteta moraalisen pohdinnan kohteeksi. Tämä on kuitenkin käsittääkseni opettajien sokea piste: ydin- ongelmaan sovelletaan välttelyorientaatiota tai ongelma delegoidaan oman toimivallan ulkopuolelle. Tirrin kirjan lähdeluettelosta ei löydy esimerkiksi Tapio Puolimatkan kasvatusfilosofian ongelmia käsitteleviä kirjoja (Puolimatka 1996 ja 1997). Niissä on paneuduttu hyvin ansiokkaasti ja syvällisesti mm. indoktrinaation ongelmaan opetuksessa. Puolimatkan kirjoissa on myös filosofisesti selkeämpi ja kiinnostavampi esitys opettajan ammattietiikan perustaksi. Tirrin kirjan ongelmanasettelut liikkuvatkin pääasiassa sosiaalipsykologisessa viitekehyksessä.

\section{Tirrin kirja on tästä}

huolimatta hyödyllinen ja kiinnostava opettajan ammattietiikkaa pohdittaessa. Otsikko vain lupaa liikaa. Kiinnostavaa olisi saada kattavampi teoreettinen esitys aiheesta ja sitä täydentämään empiiristä tutkimusta, joka kattaisi kasvatuksen ja koulutuksen koko kentän sekä paneutuisi kriittisesti myös kasvatuksen ja koulutuksen sisältöön.

\section{Kirjasta siis löytyy} vastaus ja ei löydy: Voit vältellä tilannetta, siirtää sen käsittelyn jollekulle toiselle, puuttua tilanteeseen kuultuasi asianomaisia tai osallistua yhdessä muiden ihmisten kanssa asian ratkaisuun. Taitava se, joka osaa valita oikean tavan eri tilanteissa.

\section{Lähteitä}

DEUTSCH, M. (1985). Distributive Justice. A social-psychological perspective. London: Yale University Press.

DREYFUS, H. \& Dreyfus, S. (1990). "What is morality? A Phenomenological accaunt of the development of ethical expertise." Teoksessa Rasmusse, D. (ed.) Universalism vs. communitarism. Contemporary debates in ethics. London: the MIT Press.

OSER, F. (1991). "Professional morality: a discourse approach (the case of teaching profession). Teoksessa: Kurtines, W. \& Gewirtz, J. (toim.) Handbook of moral behavior and development. Vol 2. New Jersey: Lawrence Erlbaum Associates.

PUOLIMATKA, T. (1996). Kasvatus ja filosofia, 2.p., Kirjayhtymä, Helsinki

PUOLIMATKA, T. (1997). Opetusta vai indoktrinaatiota? Valta ja manipulaatio opetuksessa. Kirjayhtymä, Helsinki.

Pekka Kalli 